\title{
O mar da alteridade e o lastro da recriação dos contos africanos de transmissão oral em Rogério Andrade Barbosa
}

\author{
Celso Sisto Silva
}

Resumo: Neste artigo tratamos de caracterizar a contribuição das matrizes africanas na literatura infantil brasileira propondo uma leitura da obra Duula, a mulher canibal, de Rogério Andrade Barbosa. Pelo exercício da recriação empreendido pelo autor, baseado no modelo do conto popular, discutimos os universos cultural, ético e estético da referida obra, aproximando-a, por fim, das teorias de Stuart Hall, como tradição popular, identidade cultural e pertencimento.

Palavras-chave: literatura infantil brasileira contemporânea; contos africanos de transmissão oral; tradição popular; identidade cultural; pertencimento.

\begin{abstract}
In this article we try to characterize the contribution of African origin in Brazilian children's literature proposing a reading of the book Duula, a mulher canibal, retold by Rogerio Barbosa Andrade. By exercise of rebuilding undertaken by the author, based on the model of the folktale, discussed the cultural universes, ethical and aesthetic of that work, bringing it closer to finally theories of Stuart Hall, as popular tradition, cultural identity and belonging.
\end{abstract}

Keywords: Brazilian children's contemporary literature; African tales of oral transmission; popular tradition; cultural identity; belonging.

Fenômeno admirável o do ovo: carne por dentro, osso por fora!

Bunkúlu bukió! Nsunha, mukati; mvese, kunganda

(provérbio cabinda) 
Para se pensar a contribuição das matrizes africanas na literatura infantil brasileira, poderíamos partir do levantamento das coletâneas dos principais folcloristas, como Sílvio Romero, Nina Rodrigues, Arthur Ramos e Câmara Cascudo, os primeiros a fazerem esses registros.

E logo nos depararíamos com uma certa imutabilidade: o modelo do conto popular clássico e a conservação de seus elementos estruturais, suas incidências e peculiaridades, que, de certa maneira, acabaram por configurar um modelo de registro para o conto popular africano como literatura infantil no Brasil.

Se nossa preocupação for identificar essa fixação no que tange à literatura infantil, também logo chegaremos a Monteiro Lobato, o primeiro escritor a preocupar-se com o registro dos contos africanos de transmissão oral, voltados ao leitor criança.

Se a idéia é prosseguir neste levantamento pode-se elencar os escritores contemporâneos que se dedicaram (ou se dedicam) a registrar esses contos, e logo chegaremos a alguns nomes, cujas obras poderiam ser apontadas como precursoras de caminhos distintos.

$\mathrm{Na}$ literatura infantil contemporânea e entre os autores que têm se dedicado a recontar as histórias africanas da tradição oral, poderíamos falar da existência de três etapas específicas. Arriscaríamos dizer que tudo o que se segue, nesta área, está circunscrito ao que chamamos de sobrevivências nativas (primeiro grupo de autores, com destaque para Joel Rufino dos Santos), reincidências nacionais (segundo grupo de autores, com destaque para Rogério Andrade Barbosa) e reconquistas míticas (terceiro grupo de autores, com destaque para Reginaldo Prandi). Esses primeiros autores, expoentes em cada uma das vertentes do reconto, serão sempre os seus fundadores no Brasil.

Ainda que o modelo do conto popular seja a base para o aproveitamento da literatura africana de transmissão oral no âmbito da literatura infantil brasileira, a história recontada é também história nova, portanto, exercício de 
recriação. O reconto, por assim dizer, pode ser visto como pertencente a um conjunto literário sempre emergente, uma vez que a cultura popular muitas vezes é vista como coisa de segunda ordem, principalmente o conto popular africano na literatura infantil brasileira. Emergente porque mutante, cambiável, em processo sempre. E conjunto porque por baixo de cada conto popular, há latentes todas as outras versões e adaptações já feitas.

A pequena historiografia do conto popular africano no Brasil pode nos lembrar que esses contos, para além de objeto estético, constituem fato sociológico, sinal de poder social, que acabam por determinar hoje, em nosso país, um interesse maior por sua produção, divulgação e permanência. Não é só o discurso verbal que faz essas obras existirem e serem importantes hoje. É a conjuntura social. É o momento político.

Dos primeiros registros da literatura africana de tradição oral no Brasil, que tinham claramente o objetivo de documentar um legado e constituir uma memória ${ }^{1}$, pudemos desembarcar aqui.

Aqui interessa-nos verificar esses modelos narrativos, a partir da análise da história Duula, a mulher canibal, de Rogério Andrade Barbosa. Interessa-nos demonstrar por que ele se enquadra na categoria de histórias africanas recontadas, apresentar as principais características de suas obras e as modificações que ele realiza no modelo "fixo" dos contos da cultura popular como um possível processo de abrasileiramento das histórias.

Para isso, examinaremos a referida obra, de acordo com a seguinte divisão: universo cultural (traços simbólico-coletivo-hierárquicos, sociológicos, econômicos, familiares, religiosos, etnológicos, históricos), universo ético (fala proverbial, exotismo, violência, elementos físicos do cotidiano, questão ritual,

\footnotetext{
${ }^{1}$ Como definem R. Gallison e D. Coste (1983), a memória é a capacidade de registrar, de fixar, de conservar e de restituir, voluntariamente ou não, quer acontecimentos ou ideias ligadas à experiência vivida, quer um material concreto ou simbólico construído.
} 
hierarquização do poder, regras sociais de conduta) e universo estético (repetição temática e estrutural, inovação temática e estrutural).

A obra de Barbosa, por fim, será lida em aproximação às teorias contemporâneas de Stuart Hall.

\section{Rogério Andrade Barbosa, balogun² das igbás}

Rogério Andrade Barbosa, além de ser escritor de vários livros infantis e juvenis, é também professor de literatura e já recebeu vários prêmios pela qualidade de sua obra. Graduou-se em Letras na Universidade Federal Fluminense (UFF) e fez pós-graduação em Literatura Infantil Brasileira na Universidade Federal do Rio de Janeiro (UFRJ). Trabalha na área de literatura afro-brasileira e programas de incentivo à leitura, proferindo palestras e dinamizando oficinas. Ex-voluntário das Nações Unidas na Guiné-Bissau, lecionou dois anos nesse país. Participa ativamente de congressos e feiras de livros. Tem mais de setenta livros publicados, alguns traduzidos para o inglês, o espanhol e o alemão. Rogério Andrade Barbosa nasceu em Minas Gerais, mas atualmente vive no Rio de Janeiro. É também membro do conselho consultivo da Associação de Escritores e Ilustradores de Literatura Infantil e Juvenil (AEILIJ). Entre todos os prêmios que recebeu, destacam-se: Altamente Recomendável para Crianças e Jovens - FNLIJ (Fundação Nacional do Livro Infantil e Juvenil) em 1988, 1990, 1993, 1995, 1996, 2000, 2001, 2002, 2003, 2004, 2005, 2006, 2007 e 2008; The White Ravens, Alemanha, em 1988 e 2001 (selecionado para o acervo da Biblioteca Internacional de Literatura Infantil e Juvenil de Munique); Lista de Honra do IBBY, Suíça, 2002; Troféu Vasco Prado (Jornada Nacional de Literatura), Passo Fundo, em 2003; Prêmio da Academia Brasileira de Letras de Literatura Infanto-Juvenil, Rio de Janeiro,

\footnotetext{
${ }^{2}$ Bologun, em iorubá, significa "chefe dos guerreiros”.

Nau Literária • vol. 09, n. 01 • O mar da alteridade e o lastro da recriaçáo dos contos africanos de transmissáo oral em Rogério Andrade 
2005; Prêmio Ori 2007 (Secretaria das Culturas do Rio de Janeiro), homenagem aos que se destacam na valorização da matriz negra na formação cultural do Brasil.

A obra de Rogério Andrade Barbosa é vasta. Nessa vertente da literatura que tem foco nos recontos de contos populares africanos, Rogério é o mais profícuo. São mais de 37 livros de recontos e outros explorando elementos das culturas africanas ${ }^{3}$. A partir da década de 1980, começa a trazer para o Brasil os contos africanos de transmissão oral das mais variadas regiões africanas.

Rogério representa um momento importante nesse panorama da literatura africana na literatura infantil, exatamente porque tem grande produção de qualidade e também porque, diferente de outros escritores que exploram esta vertente, faz todo um movimento para fora. Não é a África histórica o seu foco de trabalho. Não são os elementos da cultura africana na literatura popular brasileira que ele vai enfocar. Ele está voltado para uma África contemporânea, bem definida no que diz respeito a pluralidades, diversidades, literaturas, políticas etc. O que parece mover sua produção literária é a reconstrução de uma literatura da África traduzida por um olhar ao mesmo tempo negro e brasileiro. E é nesse sentido que vamos comentar a sua obra.

$\mathrm{O}$ autor viveu algum tempo como voluntário da ONU na Guiné-Bissau. O que mais explicita em suas entrevistas é a existência de muitas "áfricas", considerando-se os "54 países onde convivem homens e mulheres de culturas

\footnotetext{
${ }^{3}$ Contos de Itaparica (SM), Em Angola tem, no Brasil também! (FTD), A caixa dos segredos (Record), Pigmeus, os defensores da floresta (DCL), Três contos africanos de adivinhação (Paulinas), Pra lá de Marrakech (FTD), Histórias que nos contaram em Angola (FTD), Bichos da África - 4 volumes (Melhoramentos), Contos ao redor da fogueira (Agir), Sundjata, o príncipe leão (Agir), Viva o Boi Bumbá! (Agir), A tatuagem (Ediouro), Duula, a mulher canibal (DCL), Histórias africanas para contar e recontar (Editora do Brasil), O filho do vento (DCL), Como as histórias se espalharam pelo mundo (DCL), Contos africanos para crianças brasileiras (Paulinas), Três contos da sabedoria popular (Scipione), O Boi de Mamão (FTD), Os irmãos zulus (Larousse), Nyangara Shena (Scipione), Os gêmeos do tambor (DCL), Nas asas da liberdade (Biruta), $O$ senhor dos pássaros (Melhoramentos), Outros contos africanos para crianças brasileiras (Paulinas), O guardião da folia (FTD), Uma idéia luminosa (Pallas), Os três presentes mágicos (Record), ABC do continente africano (SM), Não chore ainda não (Larousse), O segredo das tranças e outras histórias africanas (Scipione), A caixa dos segredos (Record), No ritmo dos tantãs (Thesaurus).
}

Nau Literária • vol. 09, n. 01 • O mar da alteridade e o lastro da recriaçáo dos contos africanos de transmissáo oral em Rogério Andrade Barbosa 
diferentes, que se expressam em mais de mil línguas e incontáveis rituais e práticas religiosas"4. Essa ideia da multi-África tem regido suas preocupações como escritor e, por isso, tem se empenhado em recontar histórias de diferentes regiões e etnias africanas. Em sua página oficial na internet é possível perceber como a obra de Mia Couto e de Nei Lopes servem de base para o autor, que está sempre os citando ${ }^{5}$. Rogério também defende o grande legado artístico, científico, técnico e filosófico africano, pouco valorizado nos diversos campos do saber e pouco divulgado historicamente, exatamente por tratar-se de um universo regido pela oralidade. Sua preocupação tem sido a de criar condições, por meio da literatura, de colocar esse legado cultural trazido pelos escravos africanos, mas também buscado por ele, em suas andanças pela África, ao alcance das crianças brasileiras. A percepção da importância dos valores civilizatórios africanos para a sociedade brasileira é também o que o autor pretende, ao comemorar a lei $\mathrm{n}^{\circ} .10 .693$, que, como sabemos, torna obrigatório o ensino de história e cultura afro-brasileira nas escolas de ensino fundamental e médio, público e particular, em disciplinas como história e literaturas brasileiras. $\mathrm{O}$ autor está sempre atento à possibilidade que a literatura apresenta de colocar os leitores em contato com a realidade africana, seja com os contos, as lendas, as cerimônias religiosas, os festejos tradicionais e a ampla diversidade religiosa. $\mathrm{O}$ enorme painel religioso pode ser mostrado na literatura, sem intenção de doutrinação, mas como aliado para a compreensão da diversidade, afirma o autor também em seu site.

\footnotetext{
4 Informações coletadas na página oficial do escritor, na internet: http://www.rogerioandradebarbosa.com/textos mensagens/t maeafrica.asp. Acesso em: 17/08/2011.

${ }^{5}$ Do escritor moçambicano Mia Couto ele cita sempre a ideia de que "este continente é, ao mesmo tempo, muitos continentes. Os africanos são um entrançar de muitos povos. A cultura africana não é uma única, mas uma rede multicultural em contínua construção.”. Do compositor, escritor e estudioso da cultura afro-brasileira, Nei Lopes, Rogério ressalta o saber africano no campo das artes, ciências, técnicas e filosofia e se alinha com as afirmações do estudioso sobre a importância do passado cultural africano, anterior ao da civilização greco-latina, mas raramente mostrado no cinema, na televisão ou nos livros.
}

Nau Literária • vol. 09, n. 01 • O mar da alteridade e o lastro da recriaçáo dos contos africanos de transmissáo oral em Rogério Andrade Barbosa 
Em outro livro seu, no texto de quarta capa de + Contos africanos para crianças brasileiras (2004), ele diz que "hoje, graças a meus livros, realizei o sonho de menino. Viajei pelos cinco continentes e, também, participei de feiras de livros em Cuba, México, Alemanha, Colômbia e Suíça”. É essa grande mobilidade pelo mundo que dá também ao Rogério cidadão um grande lastro para seu trabalho de escritor.

O autor realiza um grande trabalho de pesquisa para recriar os contos que adapta. Tem consciência ampla de seu papel de adaptador e recriador baseado nos inúmeros relatos e textos que lê para escrever. Ele mesmo se surpreende com a intercomunicação que as histórias da tradição oral (mesmo as africanas) têm com as histórias de caráter universal, como ele mesmo afirma nas "notas de autor" que abrem o livro Duula, a mulher canibal:

De modo surpreendente, o que mais me chamou a atenção ao pesquisar, adaptar e recriar essa história baseada nos inúmeros relatos sobre mulherescanibais da tradição oral somali foi o fato desses antigos contos terem situações e passagens que nos remetem a outras histórias de conhecimento universal. (BARBOSA, 1999, p. 5)

O autor é assumidamente partidário da tese de que os contos populares têm uma origem comum ao associar a história da mulher canibal com João e Maria, Chapeuzinho Vermelho e até com passagens bíblicas, como a travessia do Mar Vermelho; ele diz:

Isto, a meu ver reforça a discutida tese dos contos populares terem uma origem comum, remodelados e adaptados de acordo com o meio ambiente e a habilidade dos narradores. Senão, como explicar que contadores de histórias no interior da Somália falem sobre temas e episódios tão conhecidos? (idem, p. 5)

Então admite que os contos populares são remodelados e adaptados de acordo com o meio ambiente e habilidades dos narradores. Nisso vem apostando 
e construindo sua obra. É exatamente o que faz, sempre buscando ampliar o painel africano para o leitor infantil brasileiro.

Assim, para a teoria do reconto nos interessa destacar esses termos: remodelação e adaptação ao meio, bem como o uso das habilidades pessoais. Esse é claramente um trabalho de buscar no fundo comum dos contos populares (que são de domínio publico), a história que se quer contar, para transformá-la em trabalho autoral.

$\mathrm{Na}$ introdução do livro $O$ filho do vento, o autor revela:

Entre as narrativas da literatura oral africana que venho pesquisando há anos, as que mais me fascinam são as dos bosquímanos: um povo nômade que habita o deserto do Kalahari" (BARBOSA, 2001, p. 5)

E fica claro, pelos textos introdutórios dos livros, muitas vezes, que o autor não só pesquisa as lendas, mas também os provérbios, as canções, as danças e os rituais mágicos dos povos africanos, especialmente daqueles a que pertence a história que escolheu transformar em livro. Ele também cita como elemento de seu fascínio a integração dos homens com os elementos da natureza e as relações que os homens mantêm com a ancestralidade.

Outra preocupação aparente do autor é contar para preservar. Diversas vezes já afirmou que a gradual ocupação do espaço tradicional de muitos povos africanos ameaça seus destinos e, por conseguinte, seu patrimônio cultural. Então, assume a condição de porta-voz desse patrimônio.

Entre as obras de Barbosa, escolhemos examinar de perto o livro Duula, a mulher canibal. E mais especificamente, os seguintes aspectos: universo cultural (traços simbólico-coletivo-hierárquicos, sociológicos, econômicos, familiares, religiosos, etnológicos e históricos), universo ético (fala proverbial, exotismo, violência, elementos físicos do cotidiano, questão ritual, 
hierarquização do poder e regras sociais de conduta) e universo estético (repetição temática e estrutural, inovação temática e estrutural).

O livro conta a história de uma moça muito bonita que, em razão de uma longa seca que assolou a região onde vivia, foi obrigada a partir com seus pais em busca de terras mais favorecidas. Os velhos morrem na longa jornada e a moça, sozinha e faminta, acaba enlouquecendo. Para sobreviver, passa a comer a carne das pessoas mortas e a beber a água imunda das poças d'água que conseguia encontrar. E, com isso, adquire repugnante aspecto e estranhos poderes, e a carne humana passa a ser seu alimento preferido. Um dia, uma família de pastores vem descendo a montanha em busca de novos pastos para seu rebanho de ovelhas e vai parar em um lugar desolador, território de Duula. O casal de irmãos, Askar e Mayran, que sai atrás de gravetos para a fogueira, já que ia passar a noite ali com os pais, é surpreendido pela chegada repentina da noite, se perde e vai parar na cabana de Duula. Os dois são feitos prisioneiros de Duula, para que ficassem gordos e ela pudesse devorá-los. As crianças conseguem enganá-la, fogem e conseguem escapar de vez, provocando a morte do monstrengo e juntando-se novamente à sua família, que, com as chuvas que voltaram a cair, retorna para suas terras.

$\mathrm{Na}$ detecção do universo cultural desse reconto, destacamos como traços simbólicos a transformação da moça bonita em monstrengo gordo, peludo, fedorento e sujo. Essa metamorfose negativa, ao contrário do que costuma acontecer na maioria dos contos, está a serviço da caracterização de um tabu, para muitos povos africanos, que é a ingestão de carne humana. Sabemos que, hoje, a religião majoritária na Somália é o sunismo, que obriga a população a não comer carne de porco e a não consumir álcool e nem praticar jogos de azar. As mulheres usam o hijab (vestimentas da doutrina islâmica).

As areias do deserto da Somália, onde esta história está circunscrita, são por si só um espaço misterioso e propiciador de muitas imagens simbólicas. 
Algumas das mais difundidas são imagens oriundas das histórias das mil e uma noites, no imaginário de outras partes do mundo, inclusive do leitor brasileiro. As caravanas de camelos, os mercadores, os comerciantes sempre em trânsito. A difícil adaptação humana e de qualquer ser vivo domina o imaginário popular. Para sobreviver num lugar como o deserto que atravessa a Somália, é preciso uma resistência fora do comum. Duula, ao mesmo tempo que é a resistente, a sobrevivente, é o monstro, que teve de ultrapassar os domínios da força humana e se bestializar, para suportar, sobretudo, as condições climáticas da região.

A simbologia do camelo, também como representante legítimo e imediato do deserto (lócus maior dessa história), tem na fé islâmica um sentido poético. Dizem que, quando a carga está para ser removida, o camelo ajoelha-se, inclinase para o lado e a carga desliza. Os islâmicos dizem que é Deus dizendo para que deixemos a carga pesada rolar até Ele. Pois esse espaço do imaginário somali, região dominada por camelos, remete-nos para a ideia de carga pesada, de sofrimento, de longas travessias, na qual é preciso ser um pouco camelo para resistir. E ainda há na figura do camelo a simbologia da persistência, uma vez que ele atravessa o deserto em seu ritmo cadenciado e inalterado. Essa persistência também está implícita na salvação das crianças desse conto, da terra (através da chuva), do retorno da família ao seu lugar de origem.

A história em questão é dominada pela simbologia do amarelo, que, em seu aspecto negativo, está associado ao medo e ao temor, e que traz para essa história um permanente estado de alerta. Esse é o clima que domina todo o conto. No entanto, o amarelo também é o símbolo da energia em movimento, o que faz com que o conto tenha uma agilidade enorme e concentre-se no caminhar, no deslocar-se, no correr e na perseguição as suas ações principais. Nesse sentido, predomina na história a aventura. O amarelo, estampado no céu do deserto somali, indica que o terrível vento do deserto vai soprar, arrasando tudo o que estiver em volta, trazendo fortes rajadas de vento e tempestade de 
areia. O conto associa o pó fino das tempestades de areia ao enxame furioso de abelhas e, com isso, faz coexistir os opostos: a fúria e o mel, o alucinante e o leve. E a oposição de forças que se debatem durante todo o conto é justamente representada pela mulher-canibal Duula e os irmãos Askar e Mayran. Mas também aparece o grande oceano, e a paisagem muda, e as gaivotas invadem o céu cristalino. No entanto, a presença do mar reforça o clima de mistério do conto, e suas águas revoltas reforçam ainda mais a dinâmica da fuga das crianças. E como o mar está ligado ao princípio e ao fim das coisas, é na história o lugar da morte e do renascimento. É por ele que as crianças escapam, é nele que Duula encontra a morte. A transitoriedade do mar é, por fim, vencida quando as crianças o atravessam, reencontram seus pais e voltam para as suas terras. A fluidez da água do mar ganha solidez na terra natal dos pastores dessa história, que precisa ser equilibrada pela água da chuva.

A Somália já foi chamada pelos romanos de País dos Aromas, em consequência do incenso que eles levavam de lá em suas transações comerciais. E o aroma é enormemente explorado nesse conto. Há um cheiro permanente de carne podre e de morte. O conto apresenta outros traços sociológicos. Percebe-se a organização de um clã, com ramificação na estrutura de vida toda organizada, tendo a família como centro, com tarefas distribuídas entre todos, mas encabeçada por um chefe; no caso do referido conto, o pai. O clima semiárido do extremo leste do continente africano impõe ao povo um comportamento distinto: em geral, suas tendas são feitas de pele de cabra. Os meninos são educados para cuidar do gado, as meninas ajudam a mãe a buscar água, lavar roupa e cozinhar. Os papéis estão bem definidos, e os casamentos só são permitidos dentro do grupo. Os pastores somalis tangem seus rebanhos para os cercados, onde passam a noite protegidos dos ataques das feras selvagens. É essa população de pastores que o conto apresenta, uma família que vive em torno da atividade de pastorear seu rebanho de ovelhas. A região de deserto árido e 
rochoso não oferece senão alimento para os abutres e é por isso que os personagens do conto estão se deslocando. Os arbustos esquálidos, ressecados, obrigam a procura de novos pastos. A família do conto se desloca através de camelos. As crianças dormem em tendas amplas e seu principal alimento é o leite espesso e gorduroso de camelo. Os traços familiares e econômicos perceptíveis no conto são generalizantes e suficientes para criarem um clima étnico para a história. A família de Samatar, o pai, é composta por ele, a mãe (que nem tem nome na história) e os filhos gêmeos, de 12 anos, chamados Askar e Mayran. Na história, durante a procura de pastos, as crianças são responsáveis pela coleta de gravetos para o fogo. Entretanto, o conto reforça a bestialização da mulher-canibal a partir da solidão e da perda da família. Seus pais são os últimos a partir em busca de novos lugares para fugir da longa seca, mas não aguentam a caminhada e morrem. Ela fica sozinha no deserto. Essa imagem tem um apelo enorme no conto.

O conto também nos oferece alguns traços religiosos: os pastores rezam a Alá, o poderoso Deus. Para o islamismo, Alá é o deus geral e supremo, criador do universo e ser supremo e onipotente. Uma série de comportamentos sociais e cotidianos decorrem da crença em Alá, assim como alguns costumes. Um dos costumes mais curiosos, citados no texto, é o espanto das crianças ao notarem que Duula serve a comida com a mão esquerda. Na região de onde vieram os irmãos gêmeos (que o texto não menciona com clareza, apenas diz que desceram a trilha das montanhas azuis) não se pode servir a comida com a mão esquerda, porque é a mão que limpa o traseiro. As referências religiosas do conto fazem eco com o universo bíblico, e o "esquerdo" tem uma conotação negativa, já que o bom, o justo, o temente a Deus é o que se situa ao lado direito.

Mas, é claro, tendo o conto um arcabouço religioso, além da súplica (que as crianças fazem de joelhos, pedindo ajuda para o mar), Duula, ao praguejar contra as crianças que fugiram dela, diz: "que a serpente do deserto pique esses 
infelizes - berrava ela de modo assustador - Que os espinhos furem a sola de seus pés - clamava a furiosa mulher-canibal" (BARBOSA, 1999, p. 26). Vale lembrar que a serpente cerastes, que vive no deserto do Saara, tem proeminências que lembram um par de chifres e fica enterrada na areia, somente com seus olhos visíveis. Pois a ideia de cobras e escorpiões e espinhos reforça, todo o tempo, o clima de "terror" do conto. E quanto maior esse clima de terror, maior o impacto da aventura e da salvação. Tudo a ver com o universo da fé.

O pequeno Askar, ao deparar com o mar, evoca a memória do passado:

- Você se lembra das histórias que nossa mãe contava? Quem sabe o mar não ouvirá nossas preces também? - recordou Askar se encaminhando para a beira da água.

Os meninos chegaram bem perto do mar. A crista do oceano bravio parecia querer atingir as nuvens. As imensas vagas elevavam-se e agitavam-se com furor, antes de quebrarem assustadoramente.

Então, Askar e Mayran ajoelharam-se na praia deserta e pediram numa só voz:

- Oh, majestoso e poderoso mar

por favor, nos deixe passar

uma terrível mulher-canibal

quer nos pegar e devorar (BARBOSA, 1999, p. 32)

Finalmente, para o universo religioso pretendido para o conto, acontece o inesperado, o milagre. E o mar se abre:

O imponente mar, com pena das crianças, abaixou suas ondas. As águas se dividiram ao meio formando um paredão esverdeado de modo que uma passagem se abriu ao longo do leito repleto de algas e conchas.

Os garotos, boquiabertos, não acreditavam no milagre que se descortinava aos seus olhos. (BARBOSA, 1999, p. 34)

Vale lembrar ainda, para reforçar os traços religiosos desse conto, que, para alguns grupos étnicos do continente africano, ter filhos gêmeos é maldição e mau presságio. Nessa cultura, organizada em aldeias de pastores, e nesse conto, ao contrário, os gêmeos são seres privilegiados, quase mágicos, que têm 
poderes especiais e muitas vezes são convertidos em heróis. É, de fato, o que acontece nessa história: os pequenos irmãos Askar e Mayran são os que provocam o extermínio da mulher-canibal.

O conto de Barbosa nos faz perceber alguns traços históricos. A Somália, lugar de origem deste conto, é uma região assolada pela seca e pela fome. A região do chifre da África tem sido acossada por prolongadas e consecutivas secas que matam animais e pessoas de sede. É esse painel que aparece no conto, sem especificar uma época ou uma data. O conto diz que os primeiros a morrer são os mais fracos (as cabras e as ovelhas), mas, quando os camelos começam a morrer, é porque a situação é realmente grave. É sob essa aura de gravidade que se estabelece o conto da mulher-canibal. No tempo impreciso do conto, os anos pioraram a seca, fazendo as pedras racharem e fumegarem sob o implacável sol.

O episódio da travessia do Mar Vermelho não só nos remete para um passado histórico, como para um passado bíblico ${ }^{6}$. Assim, o episódio da perseguição e fuga dos hebreus do Egito, acossados pelos soldados do faraó, é contado no livro do Exxodo, capítulo 14, versículos 21-31:

Então, Moisés estendeu a sua mão sobre o mar, e o SENHOR fez retirar o mar por um forte vento oriental toda aquela noite; e o mar tornou-se em seco, e as águas foram partidas. $\mathrm{E}$ os filhos de Israel entraram pelo meio do mar em seco; e as águas lhes foram como muro à sua direita e à sua esquerda.E os egípcios seguiram-nos, e entraram atrás deles todos os cavalos de Faraó, os seus carros e os seus cavaleiros, até ao meio do mar. E aconteceu que, na vigília daquela manhã, o SENHOR, na coluna de fogo e de nuvem, viu o campo dos egípcios; e alvoroçou o campo dos egípcios, e tirou-lhes as rodas dos seus carros, e fê-los andar dificultosamente. Então, disseram os egípcios: Fujamos da face de Israel, porque o SENHOR por eles peleja contra os egípcios. E disse o SENHOR a Moisés: estende a tua mão sobre o mar, para que as águas tornem sobre os egípcios, sobre os seus carros e sobre os seus cavaleiros. Então, Moisés estendeu a sua mão sobre o mar, e o mar retomou a sua força ao amanhecer, e os egípcios fugiram ao seu encontro; e o SENHOR derribou os egípcios no meio do mar, porque as águas, tornando, cobriram os carros e os cavaleiros de todo o exército de Faraó, que os haviam seguido no mar; nem ainda um deles ficou. Mas os filhos de Israel foram pelo meio do mar em seco: e as águas foram-lhes como muro à sua mão direita e à sua esquerda. Assim, o SENHOR salvou Israel naquele dia da mão dos egípcios; e

\footnotetext{
${ }^{6}$ De acordo com as idéias de Genette, expressas em seu livro Palimpsestes, esse seria um caso de hipertexto com imitação do estilo do texto bíblico.
}

Nau Literária • vol. 09, n. $01 \bullet$ O mar da alteridade e o lastro da recriaçáo dos contos africanos de transmissáo oral em Rogério Andrade Barbosa 
Israel viu os egípcios mortos na praia do mar. $\mathrm{E}$ viu Israel a grande mão que o SENHOR mostrara aos egípcios; e temeu o povo ao SENHOR e creu no SENHOR e em Moisés, seu servo. (Êx 14. 21-31)

Episódio semelhante é narrado no conto somali recontado por Barbosa. Essa intertextualidade torna ainda mais denso e interessante o conto, que também assume traços etnológicos. Sabemos que a Somália, na antiguidade, foi um importante lugar de passagem de marinheiros e mercadores, e esteve ligada ao comércio de incenso, mirra e especiarias, itens que eram negociados com os antigos egípcios, fenícios, micênicos e babilônicos. A região, historicamente, foi se convertendo ao islamismo, nova religião adotada por seus parceiros comerciais árabes. A região, que historicamente foi terra dos pastoresagricultores oromos, também está imersa na cultura dos árabes e persas. A existência, nesse território, de uma lenda que o associa a um episódio bíblico, como a travessia do Mar Vermelho, está justificada.

Curiosamente, os egípcios, na Antiguidade, chamavam a Somália de Terra de Deus (País de Pount), enquanto os romanos chamavam-na de País dos Aromas. A região foi também dominada por britânicos e franceses, o que acaba justificando a mistura que a lenda apresenta, de contos populares que aparentemente parecem ser de origem europeia. No entanto, a Somália atual é composta de muitos grupos étnicos somalis, além de benadiris, bravaneses, bantus, bajunis, indianos, persas, italianos e britânicos.

É curiosa a significação de somali:

O termo deriva das palavras "So Maal", que em língua nativa significa "vá você mesmo ordenhar um animal". Para os somalis, essa expressão um tanto tosca tinha na verdade um sentido hospitaleiro, pois era o chefe de família quem ordenhava as camelas. Assim, dar a um recém-chegado a possibilidade de fazer isso era um símbolo de amizade. (OTERO, 2006, p. 179) 
Com características geográficas peculiares, a história recontada por Barbosa situa-se em terra de contadores de histórias, também oriundos da tradição secular. Os árabes, que dominaram esse importante território de passagem, também travaram contato com as histórias dos berberes, que, ao fazerem circular pelo deserto suas mercadorias, também faziam circular suas histórias e sua cultura. O conto de Barbosa diz que os contadores de histórias também tinham a responsabilidade de entreter as crianças ao redor do fogo, enquanto esperavam a ordenha dos animais. E, na longa espera, muitas histórias eram contadas: contos fantásticos, contos de gigantes e seres monstruosos, contos de canibais de ambos os sexos. E essas histórias, de fato, compõem o rico folclore do povo somali. Muitas vezes esses monstros devoradores são considerados demônios, e é fácil perceber que Duula, no referido reconto, é caracterizada com aspectos demoníacos:

Enquanto isso, Duula crescia e engordava de modo assustador, desenvolvendo estranhos poderes.

Quem já viu-a de perto, e teve a sorte de escapar com vida, diz que ela corre mais rápido que um leopardo. Quando dispara no encalço de novas vítimas, seus enormes pés emitem um som semelhante ao de uma tempestade, ao mesmo tempo que sua cabeleira, desgrenhada e suja, jogada para trás igual a crina de um cavalo de corrida, balança alucinadamente ao sabor do vento.

Os olhos miúdos e vermelhos enxergam no escuro como se fossem os de uma coruja. Suas enormes narinas são apuradíssimas, e uma das orelhas, peluda e maior que a outra, consegue escutar os passos mais leves e distantes, inclusive o ruído de um galho partido a muitas léguas. Durante as noites, a orelha maior fica de pé, alerta, só abaixando quando Duula dorme a sono solto, dando roncos capazes de arrepiar o cabelo de qualquer pessoa.

O hábito de roer ossos humanos fez com que seus dentes crescessem feito presas de um lobo. Além disso, carrega uma longa e afiada adaga, com a qual degola e retalha o corpo dos que caem em suas mãos.

Esses relatos sobre a mulher canibal se espalharam como folhas ao vento, fazendo com que os pastores e viajantes evitassem aquela região desolada, domínio da insaciável Duula. (BARBOSA, 1999, p. 9) 
Essa também é uma história de êxodos, como muitos que caracterizam a história da África. Nesse conto, só os mais corajosos saem de suas regiões, fugindo da seca e da fome. Sabemos que, historicamente, essas condições, já bastante precárias, foram agravadas pelas guerras civis, estendendo, até o presente, o quadro desolador de miséria. Essa mesma miséria, que, no conto, obriga os personagens a compartilharem as estradas com os chacais. $\mathrm{O}$ aparecimento de chacais nessa história reforça ainda mais a atmosfera sombria da morte, uma vez que esses canídeos são necrófagos, assim como a protagonista Duula. $\mathrm{O}$ deserto também tem um revezamento da fauna diurna e da fauna noturna. E o conto de Barbosa também sublinha isso:

Askar e Mayran acordam quando o sol se erguia acima da linha do horizonte, justamente na hora em que os animais noturnos do deserto se recolhem às suas tocas cavadas debaixo da areia, cedendo espaço aos predadores diurnos. (BARBOSA, 1999, p. 14)

A fauna do deserto do Saara engloba escorpiões, insetos, o lagarto varano, a cobra cerastes, que é "a víbora chifruda", o feneco (o gato das areias, a raposa do deserto), o dassie (um roedor, um rato do deserto) e o ádax (antílope branco). A fauna noturna é maior, por conta do calor, assim como a predominância de vida subterrânea. Talvez os camelos e os dromedários sejam os únicos animais a se deslocarem durante o dia!

Todo um universo ético transparece no conto "Duula, a mulher canibal". Como já sabemos, esse tipo de conto "camufla" sempre uma fala proverbial. O livro de Barbosa, que reúne todo um conjunto de lendas, também encerra algumas possibilidades de ensinamentos, do qual a fala proverbial seria apenas a síntese. A atitude repugnante da protagonista Duula é motivada por uma situação extrema, mas é mantida pela loucura, que acaba sendo punida. Sua atitude final, na travessia do mar, também guarda uma fala proverbial: não dar ouvido às advertências dos seres superiores (dos seres mágicos, no caso o mar 
que fala, que se converte em Senhor de Todos os Mares) tem consequências definitivas. Vejamos:

Duula estava acabando de se livrar da areia que enchia seus poros quando a orelha maior captou a fuga dos meninos. Sem perder tempo, ela se mandou igual a um camelo de corrida para a beira do mar e foi logo exigindo:

- Abra rápido suas portas

poderoso mar

as crianças me pertencem

e têm de me acompanhar.

O grandioso oceano não gostou nada da maneira insolente como Duula se portou perante ele, Senhor de Todos os Mares. Mas, mesmo assim, ordenou que as águas se apartassem pra que a atrevida pudesse pasar também. E avisou:

- Pode ir, mas não ouse emporcalhar o meu leito.

Duula não deu ouvidos à advertência. Imunda como sempre, foi largando um rastro de lixo para trás. Seu último ato. O orgulhoso mar, enfurecido, fechou as ondas, sepultando a mulher-canibal sob o paredão de águas, para sempre.

Seu corpo foi devorado por tubarões famintos e nunca mais alguém ouviu falar de Duula. (BARBOSA, 1999, p. 36)

Sob o domínio do medo, a intenção educativa desse tipo de conto se estabelece: manter as crianças quietas e próximas do olhar vigilante dos adultos. Essa "educação pela pedra", para fazer eco com o grande poeta nordestino João Cabral de Melo Neto, é aqui configurada à luz da História e da Geografia de um contexto cultural específico, em que vive a família de pastores. Outra noção importante, presente subliminarmente nese conto, é a questão da cidadania: a noção de pertencimento a um clã, a uma tribo, a um agrupamento humano, oferece também uma noção de proteção e cuidado. E essa história está toda concentrada na noção de cuidado: respeitar os mais velhos, proteger os irmãos, cuidar de si, proteger o patrimônio do grupo (no caso o rebanho de cabras), proteger os valores da comunidade a qual pertencem. Os elos que saem fortalecidos nessas relações são os elos familiares, religiosos e étnicos. E a noção de continuidade, mais do que uma simples permanência, sustenta todo o conto. 
O grande monstro desse conto, na verdade, não é Duula, mas sim a mais temida das transgressões: alimentar-se de outro ser de sua mesma espécie. $\mathrm{O}$ tabu alimentar da Somália, já sabemos, se dá por conta do islamismo, que interdita a carne de porco. Muito mais porque o porco vive na sujeira e chafurda na lama e nas fezes, inclusive. $\mathrm{O}$ tabu alimentar tem muito mais ligação com o que é considerado gênero alimentício do que propriamente com a repugnância causada pelo alimento, seja por seu sabor, textura, aparência ou cheiro. No entanto, o tabu ligado à ingestão de carne humana é o mais difundido e tem raízes religiosas (rituais religiosos, simbólicos, em contextos mágicos, cerimoniais etc., quase sempre com contornos macabros) e, quando o ser humano acede a essa prática, geralmente as causas estão ligadas a acessos de loucura, ódio ou fome. Para algumas sociedades primitivas, comer inimigos vencidos e valentes significava adquirir força e valentia. É o acesso de loucura de Duula que a faz comer gente. É a privação da sanidade que a transforma em monstro.

É claro que esse conto está carregado de situações e elementos exóticos. Os principais estão relacionados à caracterização da protagonista: a sobrevivência da personagem só é possível com a ingestão de carne humana, que acaba por se converter em costume; ela tem de disputar a água com os chacais; o desenvolvimento de poderes estranhos, como correr mais que um leopardo, com os grandes pés que produzem som de tempestade; o peso excessivo; a cabeleira como crina de cavalo, que balança alucinadamente ao vento; os olhos vermelhos que permitem enxergar no escuro; as narinas apuradas; as orelhas peludas, de tamanhos diferentes, capazes de captar tudo, mesmo de longe e que durante a noite ficam em estado de alerta; os roncos fortes de arrepiar; os dentes como presas de lobo; o hábito de roer ossos humanos; o porte de adaga longa e afiada para degolar e retalhar as pessoas; o vozeirão como que saído das profundezas de uma caverna; os bufos de um leão 
faminto, emitidos durante o sono. Todos esses elementos conferem à protagonista um contorno assustador, que ainda é reforçado pelo fato de ela ser debochada e zombeteira; cultivar unhas longas e sujas; escutar demasiado; sugar o veneno de cobra (que é descrito como um líquido preto e pegajoso!), do tornozelo do menino, com a boca.

O exotismo das situações e do texto são elementos fundamentais nessa história que, por fim, "anima" outros elementos, como o mar que fala!

Há no conto, o tempo todo, uma violência implícita, justificada pela violência da natureza: o sol abrasador, causticante, que provoca sede infernal e que leva à loucura, é quem castiga e agride a vida das pessoas. E essa violência, presente do início ao fim, culmina com o corpo de Duula sendo engolido pelo mar enfurecido e devorado por tubarões famintos. Só há uma trégua na frase final: "a antiga lenda conta que Askar e Mayran reencontraram seus pais e que as chuvas voltaram a cair, de modo que os pastores puderam regressar para suas terras" (BARBOSA, 1999, p 38).

O conto popular tradicional africano quase sempre ilustra o que estamos chamando aqui de questão ritual. Nesse conto, pequenos rituais cotidianos aparecem, seja no ato de ajoelhar-se e erguer preces para o mar abrir passagem, já citados anteriormente, seja no esquema montado por Duula, com as três cabanas que são sua moradia e seu domínio: uma para executar, uma para armazenar e outra para preparar a comida. Entretanto, o ritual maior acaba sendo mesmo o ritual final do sacrifício. Duula foi imolada para que a chuva pudesse voltar a cair. E só depois disso a vida volta ao normal.

Os contos populares tradicionais também revelam regras sociais de conduta. Nessa história, algumas são muito importantes: comer carne humana é a interdição maior, mas todas as ações estão alinhadas ao fato de as condições inóspitas do lugar provocarem a loucura na jovem pastora Duula. O cotidiano da mulher-canibal gira em torno do seu território mais próximo, ou seja, as três 
cabanas, sempre com marcas da violência cotidiana: a primeira cabana está vazia e tem no centro uma estaca de madeira e manchas de sangue no chão; a segunda possui dez jarros pesados, encostados nas paredes nuas, e fede; a terceira, mais afastada das outras, possui uma entrada mais estreita, um caldeirão fumegante ao fundo e está constantemente enfumaçada por dentro. É o mistério que ronda o lugar, com índices de violência e atos de loucura. A fumaça aumenta o mistério. A situação é tão insana que envolvê-la em névoa ajuda a atribuir às ações um véu de sonho, talvez de entendimento possível apenas fora dos domínios da realidade.

O conto, por meio dos elementos físicos do cotidiano, vai apresentando seus índices de violência desde o ambiente desolador, com espinhos que furam os pés e ossadas de animais misturadas a de seres humanos, quanto na fauna de abutres, chacais, serpentes e escorpiões. É a noite que cai sub-repticiamente, é a planície a se perder de vista, são as tempestades de areia, é o caldeirão fumegante. Os personagens se alimentam de ervas secas, gafanhotos, lagartos, ratos, coelhos e outros roedores. É um mundo em ruínas que encerra as ações diárias nesse conto. O tempo do deserto sendo diferente, sendo incontrolável e imprevisível, reforça a situação de instabilidade dos personagens.

Também é comum, no conto tradicional africano, a percepção de uma hierarquização do poder. Em Duula, a mulher canibal, Alá é a força suprema, secundado pela natureza (aqui representados pelo Sol e pelo Oceano, Senhor de Todos os Mares). A seguir estão o pai (chefe da família), depois a mulher, depois as crianças. Até no reino animal há uma hierarquia positiva e uma negativa. O camelo representa o lado positivo, a serpente chifruda representa o lado negativo. E Duula, o ser supremo, é capaz de derrotar tudo, inclusive sobreviver às inclemências da natureza! Curioso é que Duula é o nome de uma Montanha, na Somália, cujo nome completo é Buuraha Duula Gaduud e fica em Gedo. Segundo a geografia do lugar, um de seus rios principais, o rio Juba, 
depois de atravessar várias regiões, pode ser visto com suas águas vermelhas se misturando com as águas azuis do oceano. Tudo a ver com a história de Duula, a mulher canibal! Mas Duula, curiosamente, também é o nome de uma personagem da série de filmes Guerra nas Estrelas. Nele, Duula é um juiz da Corte Suprema de Ahto City. Irônico, não?

Por fim, interessa-nos o universo estético desse conto. Há, nesse tipo de história, uma repetição temática: o ser, transformado em besta-fera, que um dia é punido pelo destino e destruído por forças supremas. Mas o que nos parece mais interessante na construção desse conto, de temática universal, e que funciona também como uma inovação, são as intertextualidades que ele proporciona. $\mathrm{O}$ clássico João e Maria está presente nessa história: as crianças perdidas não vão bater numa casinha de chocolate, mas vão dar nas cabanas de Duula, são aprisionadas e mantidas em cativeiro para engordar, a fim de serem devoradas pela (bruxa?) mulher-canibal. A situação é a mesma. Outro diálogo do conto de Barbosa é com o clássico Chapeuzinho Vermelho. No reconto de Barbosa, o conhecido diálogo de Chapeuzinho com o Lobo é transferido para o diálogo das crianças com Duula:

Os pastorzinhos jamais tinham visto uma pessoa tão horrorosa e suja em suas vidas.

- Po... po... por... que a senhora tem os olhos vermelhos desse jeito, tia? gaguejou Mayran.

- É por causa da fumaça - respondeu a balofa arreganhando os dentões.

- E esses dentes que parecem de lobo? - perguntou Askar.

- São de nascença. Mas não fiquem assustados, Não farei nenhum mal a vocês. Vivo aqui, sozinha e escondida, porque todos me acham muito feia disfarçou, numa voz fingida e chorosa. - Comam - disse ela, estendendo duas tigelas fumegantes para os esfomeados meninos. (BARBOSA, 1999, p. 20)

A dúvida maior: o que será que ela deu para as crianças comerem? Foi carne humana? O conto não esclarece, mas os diálogos com outros textos continuam. E histórias de ogros e comedores de gente sempre estiveram presentes na literatura de muitos outros países, tanto no plano do imaginário 
quanto no plano histórico. Basta lembrarmos, por exemplo, que, na história do Brasil, o tema do canibalismo aparece em diversos relatos feitos pelos navegadores portugueses, espanhóis, franceses e holandeses que por aqui estiveram no período do descobrimento e durante a colonização. As narrativas de viagens desses navegadores citam exemplos de canibalismo em rituais de sacrifício humano de certos grupos indígenas. A carne dos prisioneiros rivais era consumida como símbolo da força, vitalidade e das qualidades do guerreiro sacrificado. E, para não esquecermos, Gonçalves Dias, o poeta brasileiro, narra esses episódios em seu épico "Canção do Tamoio".

No conto em questão há ainda uma intertextualidade com o clássico Barba Azul. No entanto, em Duula, o quarto de matar as esposas se duplica e vira a cabana onde as vítimas são armazendas e sacrificadas, em pesados vasos, os corpos. E há ainda a proibição da mulher:

Todos os dias Duula se embrenhava no deserto à procura de coelhos e outros roedores. Deixava as crianças arrumando as cabanas, porém antes de partir sempre avisava:

- Não mexam nos vasos de barro. (BARBOSA, 1999, p. 22)

E, por fim, a redenção, pontuada pela ligação com o episódio bíblico, da travessia do Mar Vermelho, já citado anteriormente aqui, nesta pesquisa.

Em se tratando de um reconto de um conto popular, que Barbosa aponta como originário de lendas somalis, o texto de Duula obedece aos padrões narrativos desses tipos de contos. $\mathrm{O}$ que o autor defende aqui, para explicar as “contaminações" dessa história com outros contos de "origem" europeia, é a possibilidade de uma origem comum para os contos populares universais. Sendo assim, temos os elementos obrigatórios: a passagem rápida do tempo, que também é indefinido e o leitor não tem possibilidade de saber em que época se passa a história nem em quantos dias esses episódios se desenvolvem; a exploração de onomatopeias, por exemplo o "clap-clap" dos pezões dela, 
pisando com força e pesadamente a areia ("o clap-clap inconfundível dos pezões de Duula aumentava cada vez mais de intensidade", p. 28); e o final feliz (o monstro eliminado, as crianças salvas, a chuva e o retorno para o lugar de origem). Há ainda, no texto, uma expressão corriqueira dos contos populares, que talvez soe como uma impropriedade: "seu corpo foi devorado por tubarões famintos e nunca mais alguém ouviu falar de Duula" (p. 36). Ora, se nunca mais "alguém ouviu falar de Duula", a história não teria se espalhado e permanecido, não?!

Pois é neste mar de histórias oriundas da tradição oral que navega a produção literária de Rogério Andrade Barbosa destinada ao leitor criança. Fortemente lastreada pelo legado histórico da cultura popular, pelos ecos das vozes dos griôs e narradores orais de uma África tão legítima quanto ressignificada pela ação do imaginário, o autor realiza seu trabalho cartográfico.

Do ponto de vista social, este cruzar de oceanos literários colabora com a construção de uma visão cada vez mais positiva das diferenças, sejam elas sociais, culturais ou mesmo econômicas. O leitor brasileiro, ao ver retratado nos livros, em número cada vez maior, costumes, tradições, crenças, sabedorias e modos de vida dos povos africanos ou de seus descendentes, poderá desenvolver uma visão positiva em relação à diferença e à multiplicidade das culturas que estão na base da cultura brasileira. Certamente isso pode ajudar a minimizar o preconceito racial, rechaçado na Constituição Brasileira, mas tão camuflado em diversos domínios culturais e instituições.

Entretanto, os leitores brasileiros, afrodescendentes, especialmente, ao verem surgir cada vez mais obras que, de um modo ou de outro, valorizam esse segmento cultural também tenderão a desenvolver uma visão cada vez mais positiva de suas origens, raízes e história, com benefícios, inclusive, no que diz respeito à auto-estima: poderão se identificar com este universo, sem medo de serem ridicularizados (pelo menos é o que se espera!). 
De todo modo, a história, remodelada por Barbosa, adaptada a outra geografia, é um grande e belo exercício de reinvenção. Não é esse o processo de atualização pelo qual passam os contos populares? Mesmo os que supostamente teriam origem africana ou uma origem comum?

Temos sido inclinados a considerar a obra de Barbosa em dois sentidos. Primeiramente, como um fator de enriquecimento da cultura negra no Brasil. Em segundo lugar, como um depositário da resistência. Partindo da necessidade de ampliação da memória do povo africano, o autor vai buscar contos que mostrem aspectos da cultura africana ainda desconhecidos no Brasil. Com isso, fornece "material" para ampliação da visão da herança, para ampliação das identidades, para consolidação da resistência. Nesse caminho, também filiamos as obras de Barbosa com o pensamento de Stuart Hall, especialmente quando ele diz:

\begin{abstract}
Luta e resistência - mas também apropriação e expropriação. [...] O que vem ocorrendo freqüentemente ao longo do tempo é a rápida destruição de estilos específicos de vida e sua transformação em algo novo. A "transformação cultural" é um eufemismo para o processo pelo qual algumas formas e práticas culturais são expulsas do centro da vida popular e ativamente marginalizadas. Em vez de simplesmente "caírem em desuso" através da Longa Marcha para a modernização, as coisas foram ativamente descartadas, para que outras pudessem tomar seus lugares (HALL, 2003, p. 248)
\end{abstract}

O que Stuart Hall condena é a manipulação do popular, defendendo a ideia de que a tradição popular é o lugar mais forte e poderoso de resistências às reformas, e que foi, desde sempre, o local que o pensamento hegemônico escolheu para minar, caracterizando-o como foco do pensamento retrógrado, conservador e anacrônico (2003, p. 248). Hall reivindica para a cultura popular o status de "terreno sobre o qual as transformações são operadas" (idem). Não são reformas, são transformações. Por isso, o autor afirma que no interior da cultura 
popular há um duplo movimento, que a faz oscilar entre dois polos: conter e resistir.

De algum modo, a obra de Barbosa também propõe isso. Oferecendo novos exemplos de africanidade, com os contos trazidos de diferentes regiões e de várias etnias africanas, o autor amplia os conteúdos e os conhecimentos, além de oferecer novas maneiras de resistir a um achatamento cultural.

Somos tentados a acreditar que Barbosa tem como projeto desenhar para o leitor brasileiro uma ideia de nação africana. E, para isso, também precisamos das palavras de Hall, que, lendo Benedict Anderson, afirma que "as nações não são apenas entidades políticas soberanas, mas comunidades imaginadas", (HALL, 2003, p. 26). Faz parte do jogo proposto (ou imposto?) pelo conjunto cultural, que constrói a ideia de nação, dirigir-se a um sujeito também imaginado. Nesse processo, as manipulações são possíveis. Por isso é necessário ampliar essa visão de nação africana. E essa tem sido uma das tarefas da literatura de Barbosa.

Hall tem levantado em seus trabalhos ${ }^{8}$ uma série de questões relacionadas ao "pertencimento" e a relação com a terra de origem. Tal qual o mecanismo de atuação das comunidades transnacionais, que são rede e local da memória, essas famílias ampliadas é que fazem a ponte entre os dois lugares (idem). A literatura de Barbosa, também fazendo parte dessa rede de informação, dessa família ampliada, e sendo também receptáculo da memória, oferece ao leitor brasileiro essa terra de origem, que lhe diz respeito seja na cor da pele, seja como herança nacional, de forma alargada. É a constituição de outro canal de informação, mas é também o convite para pensar a África olhando daqui para lá, com elementos trazidos de lá. É a possibilidade de uma multivisão. Barbosa, com sua obra, também faz essa ponte e se constitui numa outra voz, que não é a da família, que

\footnotetext{
${ }^{7}$ Segundo Stuart Hall, a expressão é de Benedict Anderson.

${ }^{8}$ Em especial, no texto "Pensando a diáspora: reflexões sobre a terra no exterior". In: HALL, Stuart. Da diáspora: identidades e mediações culturais. Belo Horizonte: Editora UFMG, 2003. p. 25-50.
} 
não é a voz mais próxima, mas que se configura como uma voz principalmente recente. A memória, estendida aos dias de hoje, se renova. Esse reavivamento da tradição pode ser percebido pelo leitor. A noção de "terra de origem" se renova, se amplia, se intensifica. Uma nova identidade cultural é construída e preservada também a partir da literatura infantil. Para utilizar também uma expressão explorada por Hall, podemos dizer que as "identificações associativas" com as culturas de origem permanecem fortes, mas o autor também nos lembra que, depois de gerações sucessivas, os "locais de origem" não são mais a única fonte de identificação (idem). O que faz a literatura de Barbosa é potencializar, na atualidade, esses elos entre Brasil e África.

Ao oferecer outros modelos para a nossa identidade cultural, a obra de Barbosa também nos fornece elementos para concebermos a identidade, a diferença e o pertencimento. É também Stuart Hall quem diz que a identidade cultural carrega consigo muitos "traços de unidade essencial, unicidade primordial, indivisibilidade e mesmice" (HALL, 2003, p. 28). Para que o leitor brasileiro chegue a construir um sentimento amplo de pertencimento, é preciso que essa identidade cultural seja construída de modo orgânico, contínuo, reflexivo, variado, ligada a um conjunto maior, complexo, consistente e passível de repetição. Os contos populares também atuam nessa construção, e a literatura de Barbosa, de certo modo, pode ser um caminho para essa reconstrução, desde que as diferenças e disjunturas não sejam ignoradas nesse processo e que as identidades não deixem de considerar as relações de poder. Trazer essas histórias africanas para o âmbito da literatura infantojuvenil brasileira é tanto uma maneira de enfrentar o poder hegemônico quanto de injetar poder em uma literatura vista como de uma minoria. Para isso, também é preciso considerar o conceito de identidade cultural propagado por Stuart Hall:

Essencialmente, presume-se que a identidade cultural seja fixada no nascimento, seja parte da natureza, impressa através do parentesco e da 
linhagem dos genes, seja constitutiva de nosso eu mais interior. É impermeável a algo tão "mundano", secular e superficial quanto uma mudança temporária de nosso local de residência. A pobreza, o subdesenvolvimento, a falta de oportunidades - os legados do Império em toda parte - podem forçar as pessoas a migrar, o que causa o espalhamento a dispersão. Mas cada disseminação carrega consigo a promessa do retorno redentor. (HALL, 2003, p. 28)

A literatura de Barbosa oferece um retorno redentor à África mãe, vista das mais variadas formas em seus diferentes livros. A visão múltipla que as histórias tradicionais de diferentes grupos étnicos podem oferecer amplia mesmo a capacidade de influir na construção da identidade, dividindo com outras agências a responsabilidade na formação desses sujeitos leitores. E que, ao contrário do que acredita Hall, sejam, sim, permeáveis à mistura advinda de outros locus, mesmo para aqueles que não possuam em sua natureza genética um parentesco imediatamente reconhecível.

Se adotarmos a ideia de Hall para identidade cultural, veremos que, por meio dos contos populares, é possível, para o leitor, "estar primordialmente em contato com um núcleo imutável e atemporal, ligando ao passado o futuro e o presente numa linha ininterrupta" (HALL, 2003, p. 29). Os contos populares são esse núcleo e, mesmo constantemente atualizado, cada vez que um autor o retoma e o conta, ele guarda essa fidelidade às origens, sua autenticidade com a tradição. É isso que Barbosa propõe quando traz para a literatura infantil brasileira esses contos populares africanos de variadas etnias. A despeito de estarmos chamando todas essas histórias populares de contos, também faz sentido aproveitar a ideia de Hall, referente aos "nossos mitos dominantes". Os contos populares teriam também todo o potencial real "de moldar nossos imaginários, influenciar nossas ações, conferir significado às nossas vidas e dar sentidos à nossa história" (HALL, 2003, p. 29). Cada vez que uma história popular africana ganha o território brasileiro, conquista leitores, se difunde, mais 
se estreitam os laços que dizem respeito às origens do povo brasileiro. $\mathrm{O}$ que Barbosa talvez não dimensione é que sua obra vai ganhando força para interferir numa visão bastante ampla de pátria. Não uma pátria exclusivamente africana ou brasileira, mas uma pátria afro-brasileira, que historicamente vai além do exclusivismo da recusa de uma homogeneidade. Uma pátria múltipla, que reconhece cada singularidade, mas que é também o resultado da mistura de todas essas. Há quem prefira chamar isso de mestiçagem.

Para pensarmos no valor que esse legado de histórias da tradição pode adquirir para o leitor brasileiro, é preciso que não esqueçamos, para usarmos, mais uma vez, as palavras de Stuart Hall, que "a identidade é irrevogavelmente uma questão histórica. Nossas sociedades são compostas não de um, mas de muitos povos. Suas origens não são únicas, mas diversas" (HALL, 2003, p. 30). Talvez tenhamos de repetir incansavelmente essa constatação, para que nas representações artísticas desse país não se deixem de considerar que essas histórias também nos dizem respeito. Que conhecê-las, disseminá-las e amá-las faz parte de um projeto maior de preparação para enfrentarmos o "monstro" da modernidade, como talvez o pense Hall. Estamos marcados pela "conquista, expropriação, genocídio, escravidão, pelo sistema de engenho e pela longa tutela da dependência colonial" (HALL, 2003, p. 30). Os leitores brasileiros, de forma paulatina por intermédio da literatura, e, quem sabe, afetuosamente, precisam compreender que há uma pátria construída aqui com a soma de raízes dos quatro cantos do mundo. E que essa visão nos livra da ingenuidade de considerarmos que a distância que nos separa de cada um desses povos é justamente a cor da pele. Não há distância! Há, muitas vezes, a percepção de uma fusão, mas ainda é necessária uma ampla divulgação para que um maior entrelaçamento dos elementos culturais africanos, indígenas e europeus seja autenticamente reconhecido. Em todas as áreas. Sem hipocrisia. Não é esse um exercício de anulação das diferenças, mas um processo que vai além do que chamamos de 
"zona de contato". Apesar da "co-presença espacial e temporal dos sujeitos anteriormente isolados por disjunturas geográficas e históricas" (HALL, 2003, p. 31), essas trajetórias se cruzam e se fundem. Portanto, esse legado do imaginário africano, disponibilizado pela literatura de Barbosa, serve ainda de exemplo de como a arte pode lidar com as relações de poder. No interior de um sistema cultural que se amplia, que se multiplica, que se expande, é possível produzir outra ideia de pátria tomando esses variados exemplos que a literatura africana nos oferece. Não nos interessa, nesse momento, uma lógica disjuntiva; pelo contrário, queremos um empreendimento de igualdade, via valor atribuído a todas as produções literárias da cultura popular, para que se mantenham as características também das dessemelhanças. Aí está a originalidade! E, quem sabe, a salvação?!

\section{Referências}

GAllissON, R. COSTE, D. Dicionário de didática das línguas. Coimbra: Livraria Almedina, 1983.

BARBOSA, Rogério Andrade. O filho do vento. São Paulo: DCL, 2001

BARBOSA, Rogério Andrade. Duula, a mulher canibal. São Paulo: DCL, 1999.

BIBLIA SAGRADA. Tradução e edição autorizada da Bíblia Reina Valera $\left(1^{\mathrm{a}}\right.$ edição, $2^{\mathrm{a}}$ impressão). Rio de Janeiro: Unipro Editora, 2009.

GENETTE, Gérard. Palimpsestes: la littérature au second degré. Paris: Éditions Du Seuil, 1982.

OTERO, Edgardo. A origem dos nomes dos países. Tradução Luciano Vieira Machado. São Paulo: Panda Books, 2006.

HALL, Stuart. Da diáspora: identidades e mediações culturais. Belo Horizonte: Editora UFMG, 2003. 